\title{
Theoretical and Practical Aspects Regarding the Investigation of the Criminal Offence of False Testimony
}

\author{
By Elena-Ana Iancu*
}

\begin{abstract}
The process of building social capital is closely correlated to the manner in which personal safety and human security are ensured. It is also influenced by the correctness, clarity and accuracy of the statements a person makes before the judicial bodies (in a criminal case, a civil case or other judicial procedures), as well as by their omissions, with the form of guilt required by the law. Untrue testimonies may lead to situations that constitute offences falling within the realm of obstruction of justice. They also contribute to a decrease in the level of trust in the state institutions' maintenance of emergency situations or a state of crisis, as well as the decrease of trust among fellow citizens, regardless of whether they are participants in the criminal process or members of certain communities. This article is aimed at highlighting the legal content and the constituent elements of the criminal offence of false testimony, as they result from Article 273 of the Romanian Criminal Code, while simultaneously presenting the particularities of the process of crime investigation. The discussion of this topic is interdisciplinary, as during the process of investigation of a false testimony offence, the evidence-gathering procedures that may be ordered in the case vary, depending on the concrete circumstances in which the act was committed, the material element of the objective side and the circumstances surrounding the active or passive subject. The identification, reporting and decoding of simulated or dissimulated behaviours which may have negative consequences on actions aimed at ensuring public order and safety, national security and security in the context of global communities, are of particular importance.
\end{abstract}

Keywords: false testimony, criminal offence, investigation, crisis, perjury

\section{Introduction}

Article 57 of the Romanian Constitution provides for the manner in which constitutional rights and freedoms ought to be exercised. In this sense, good faith and respect for the rights and freedom of citizens are attributes that contribute to ensuring the safety of the individual and safeguarding the values that are protected by law.

In order to ascertain that justice is achieved, it is essential that the role and specific activities of the different judicial bodies be presented in a correct and clear manner, since this may have ramifications on the relationship between the

*PhD Habil., Professor, Doctoral School of Law, "Alexandru Ioan Cuza" Police Academy, Bucharest, Romania; Dean, Faculty of Juridical and Administration Sciences, Agora University of Oradea, Romania. E-mail: anaelena2009@yahoo.com. 
bodies that are involved. Literature on the subject emphasises the meaning of the concept of justice ${ }^{1}$ as a particularly important value, upon which the entire rule of law is based.

If justice cannot be attained, the consequence is a decline of trust among the participants in the criminal proceedings, obviously depending on the situation of each participant. An important aspect is the reciprocity of liability, as this sanctions both the deeds of the natural persons or legal entities who, through their behaviour, caused a disservice to the judicial bodies, and the deeds of circumstantiated persons who are charged with specific duties in the achievement of justice. Untrue answers or intentionally incomplete answers provided to the questions asked by the judicial body, pose a threat to the values that are being protected, regardless of whether they come from a natural person or a legal entity.

Such answers, if substantiated by official documents concluded and signed by both parties, will be used as means of proof in criminal proceedings. Each person will be a perpetrator of the deed, even if several people have apparently committed the material element of a single criminal offence. The criminal offence of false testimony is a crime in persona propria, and each participant will be held accountable as a perpetrator. Explanations based on dynamic knowledge have been highlighted in the criminological literature. ${ }^{2}$ Some authors, referring to sociological studies, present two types of justice, as follows: "distributive (to give to everyone what is due to them, i.e. what they deserve) and retributive (to restore the previously achieved order by means of an appropriate reward or sanction)."3

In this paper, we will pursue the following objectives:

a) To analyse the constitutive content of the crime of false testimony as it results from the legal text, in order to understand the manner in which the Romanian legislator criminalized the facts that can be legally classified as falling under the legal text concerned;

b) To identify and present comparatively examples of legal texts that criminalize similar situations in the criminal legislation of Romania, the Federal Republic of Germany, Hungary, Italy, and Greece, examining the common aspects and differences that might generate ambiguities in practice, especially in the case of investigation of international crimes, given that knowledge of this subject matter might contribute to the provision of safety;

c) To present some specific elements in the evidentiary proceedings, depending on the circumstantiation of the active subject and in relation to the Romanian legislation, in view of emphasizing the theoretical and practical implications this has to the stages of the criminal proceedings;

d) To highlight the importance of good-faith conduct in the relations between the possible subjects of this criminal offence and the authorities that achieve

\footnotetext{
${ }^{1}$ Duvac (2010) at 437.

${ }^{2}$ Cioclei (2016) at 36.

${ }^{3}$ Lopez (2009) at 104.
} 
justice, while also ensuring the safety of the individual by increasing the degree of trust between peers and in relation to the judicial bodies.

\section{Aspects of Material Criminal Law related to the Criminal Offence of False Testimony}

\section{Regulation of the Criminal Offence in the Romanian Criminal Code}

Title IV, bearing the marginal name "Offences Against the Achievement of Justice" ("Obstruction of Justice") of the Criminal Code of Romania, provides for the deeds that may be classified as criminal offences of the type indicated by the legislator in Article 273, entitled "False Testimony." By analysing the legal text, we note that the offence is presented in three paragraphs: the first refers to the standard, simple form of the offence, the second to the aggravated form and the third paragraph provides for a special cause of impunity.

The generic legal object consists of the social relations that protect the achievement of justice. The special legal object protects the social relations that contribute to the discovery of the truth by giving true answers to the questions posed by the authorities administering justice.

The material object is missing, the action or inaction that achieves the objective side (content), posing a threat to the value being protected from the moment when untrue answers are expressed. The statement of the witness or the report drawn up by the expert is the means by which the deeds are committed.

The active subject is circumstantiated (qualified). In the simple form, they are the witness: "[...] any person who is aware of facts or factual circumstances that constitute evidence in a criminal case."

In the aggravated form, the three first sections list the circumstances related to the active subject, while the fourth section relates to the circumstances regarding the deed, referring to the punishment provided for by law as being "the punishment of life imprisonment or imprisonment for 10 years or more."

With reference to the active subject, the aggravated form indicates other circumstances relating to the witness: "witness with protected identity or witness subject to control by the Witness Protection Program." Regarding the protection of witnesses, specific regulations are included in the special law on the matter ${ }^{7}$ and in the Criminal Procedure Code ${ }^{8}$ which also relates to the use of an undercover investigator. ${ }^{9}$ Undercover investigators may be heard in the criminal proceedings under the same conditions as threatened witnesses. ${ }^{10}$ The active subject may only

\footnotetext{
${ }^{4}$ Art. 114, Para. 1 of the Romanian Criminal Procedure Code.

${ }^{5}$ Indicated in Para. 2.

${ }^{6}$ Provided for in Para. 2a.

${ }^{7}$ Law no. 682/2002 on witness protection

${ }^{8}$ Section 5, with the marginal name "Witness Protection" (articles 125-130) in Chapter II "Hearing of Persons" contained in Title I, with the marginal name "Evidence, Methods of Proof and Evidentiary Processes".

${ }^{9}$ Art. 138, Para. 1, letter g.

${ }^{10}$ Art. 148, Para. 8.
} 
be a circumstantiated person, either in the sense of "a person who draws up an expertise report" or in that of an interpreter. ${ }^{11}$

In addition to the state (as holder of the social values attributed to the achievement of justice), as the general passive subject, there may be a secondary passive subject, more specifically, the natural person or legal entity who has been harmed by the action or inaction committed.

Additional terms that are relevant to the discussion are the objective and subjective components. The objective component is the material element, which depends on the capacity of the active subject in relation to the evidentiary process ordered and the method of proof by which the material element is achieved (e.g. statement, expertise report, technical-scientific finding report). As a result, the material element may be achieved either by "making false statements" or by "not saying everything one knows." The objective component includes certain essential requirements, relating to: the category of the case, the facts that are typical for the forms of this offence constituting either a criminal case or a civil case; "any other proceedings" in which witnesses are heard; the facts, which should be essential and examined; and the circumstances, which should be essential and examined.

The subjective component is relevant when the offence is committed intentionally. The motive and the purpose of the crime have legal relevance for the individualization of the punishment. ${ }^{12}$

Criminal participation may take the form of complicity or instigation. The witness cannot be a co-perpetrator. If there were several experts appointed to carry out the method of proof, they could be co-perpetrators if they had a criminal resolution regarding the realization of the material element. A similar situation is that of interpreters in the event that they perform, on the basis of an agreement, an activity not permitted by law. This offence is considered to have occurred at the moment when the action/inaction that forms the material element has been achieved, and it is not relevant for the retention of this classification whether they influenced the solution pronounced, or to what extent.

\section{Elements of Comparative Law}

\section{Regulation in the Criminal Code of the Federal Republic of Germany}

In German criminal law, the special part of the Criminal Code includes a section bearing the marginal name "False Testimony and Perjury." 13 From this section we may learn that the Criminal Code of Germany distinguishes between the false testimony made without taking an oath ${ }^{14}$ and that made under oath. ${ }^{15}$ The term "oath" refers to three possible situations: ${ }^{16}$ an affirmation in lieu of oath; an

\footnotetext{
${ }^{11}$ Art. 148, Para. 2, letter c.

${ }^{12}$ Art. 74 of the Criminal Code.

${ }^{13}$ Section IX, §153- $\$ 162$.

${ }^{14} \S 153$, "False testimony made without taking an oath."

${ }^{15} \$ 154$ "Perjury".

${ }^{16} \S 155$, assimilated form (affirmation equivalent to an oath).
} 
invocation of a previous oath; and an invocation of a previous affirmation in lieu of oath. The legislator imposed two requirements, one regarding the entity before which the false testimony is given, i.e. the false testimony must be given before a court or another institution empowered to take testimonies under oath. The second requirement relates to the oath itself.

The punishment provided by law is imprisonment, ranging from 3 months to 5 years in the case of the criminal offence, ${ }^{17}$ and imprisonment for at least one year in the case of the criminal offence, for the simple form. ${ }^{18}$ For the mitigated form, concerning less serious cases, the penalty is imprisonment ranging from 6 months to 5 years.

Part of the German Criminal Code ${ }^{19}$ relates to a person making a false sworn affidavit or falsely testifying while referring to such an affidavit, an offense punishable by up to 3 years imprisonment or a fine. The following sections indicate possible reasons for reducing the punishments or waiving the application of the punishment, such as if the false testimony was given in order to favour a relative, in cases where the requirements are met, ${ }^{20}$ or if the false testimonies were corrected before producing the consequences to which the legislator explicitly refers. ${ }^{21}$

\section{Regulation in the Criminal Code of Hungary}

The Hungarian Criminal Code relates to "Crimes against the Judicial System." 22 According to this Code, the forms of the criminal offence and the penalties provided by law for the offence of false testimony (false accusation) differ, depending on the type of case in which the false testimony is given. This means that the legislator distinguishes between criminal cases, civil cases or conventional actions or other judicial actions or disciplinary actions, and also between crimes of a higher value or ones for which the special maximum penalty is life imprisonment. In addition, the Hungarian legislator does not make express reference to testimony given under oath or without taking an oath. The code relates to false testimony, ${ }^{23}$ and contains provisions regarding the criminal offence that is the subject of our article. ${ }^{24}$ The code provides for an offence committed by an active subject, the witness who gives "false testimony before the authority concerning an essential circumstance... or suppresses evidence." 25 The code also differentiates between as active subject who is circumstantiated by the capacity of expert or special adviser, and an interpreter or translator, if they commit the typical action or inaction provided for by paragraph $1 .{ }^{26}$

\footnotetext{
${ }^{17}$ Provided for in $\$ 153$.

${ }^{18} \$ 154$.

${ }^{19} \$ 156$ "False sworn affidavit in lieu of oath."

${ }^{20} \$ 157$.

${ }^{21} \$ 158$.

${ }^{22}$ Chapter XXVI, Sections 268-289 of the Hungarian Criminal Code, known by the marginal name "Crimes Against the Judicial System."

${ }^{23}$ Section 272, "False Testimony."

${ }^{24}$ Sections 273, 274 and 275.

${ }^{25}$ Section 272 Para. 1.

${ }^{26}$ Para. $2 \mathrm{a}$ and $2 \mathrm{~b}$, respectively.
} 
The legislator has imposed a number of essential requirements, including one that is related to the entity before which the false testimony is given, meaning that the false testimony must be given before an authority. Another requirement relates to the type of procedure or action that has taken place, which might lead to a different legal classification. Thus, the punishment provided by law is imprisonment from one to five years if the false testimony is given in a criminal case, regardless of the criminal offence to which it refers. The exception is in the case of a crime for which the maximum punishment is life imprisonment, in which case false testimony is punishable by imprisonment from two to eight years. ${ }^{27}$ In the event that the false testimony is given in a civil case, the sanction is imprisonment for up to three years. The exception is when the civil case concerns a "particularly considerable value or any other form of interest that is considered particularly substantial", ${ }^{28}$ then the penalty provided for is imprisonment from one up to five years.

It should be noted that a provision exists for elements of criminal procedural law, as it states that criminal proceedings "may be instituted in connection with a case for which false testimony was presented" solely at the request of the authority handling the initial process. ${ }^{29}$ The same section refers to the limitation period, showing that it begins on the date of the "conclusion of the principal action".

The Hungarian criminal law explicitly stipulates that this offence may be committed by way of negligence (basic intent), as a form of guilt, in which case the punishment is imprisonment for up to one year. By analysing the punishments provided by law, we have determined that the offence has a standard form, ${ }^{30}$ an aggravated form, ${ }^{31}$ and two mitigated forms. ${ }^{32}$ Notably, the legislator exhaustively indicates the cases in which the deeds will not be retained as typical false testimony offences, ${ }^{33}$ as well as the case of special punishment or exemption from criminal liability. ${ }^{34}$

\section{Regulation in the Criminal Code of Italy}

In Italian criminal law, judicial activity is protected in a special part of the Italian Criminal Code. ${ }^{35}$ As can be seen, the legislator distinguishes between testimonies made under oath in civil or criminal cases, before the judicial bodies and procedural fraud, and relates separately to false testimonies. ${ }^{36}$ The active subject is circumstantiated differently in the legal content of the criminal offence,

\footnotetext{
${ }^{27}$ Section 272, Para. 4.

${ }^{28}$ Section 272, Para. 5.

${ }^{29}$ Section 274.

${ }^{30}$ Section 272, Para. 4, thesis I.

${ }^{31}$ Section 272, Para. 4, thesis II; Para. 5, thesis I and II.

${ }^{32}$ Section 272, Para. 6 and in Section 273, respectively.

${ }^{33}$ Section 275 Para 1a-1c.

${ }^{34}$ Section 275 Para 2.

${ }^{35}$ Title III, with the marginal name "On Crimes Against the Administration of Justice", in Part. I "On Crimes Against Judicial Activity", articles 361-384-ter.

${ }^{36}$ Art. 372, the "False Testimony." Additional articles on the subject include Art. 371, "False Oath of the Party", and Art. 374, "Procedural Fraud".
} 
and instead of referring to aggravated forms, for example, the code includes different legal classifications. Thus, in an article with the marginal name "false testimony", 37 the active subject is circumstantiated, referring to the person who submits the "witness testimony", whereas in a previous article, with the marginal name "False Oath of the Party", 38 the active subject is "the one who, as a party" swears falsely, though this relates only to civil trials. It should be noted that in the case of an active subject circumstantiated by the capacity of "expert or interpreter", the legislator assigned an article ${ }^{39}$ with the marginal name "False Expertise or False Interpretation", on the condition that the expert or interpreter be appointed by the court.

Another article found in the Italian Criminal $\operatorname{Code}^{40}$ contains provisions applicable in the event that, during the criminal prosecution, the prosecutor or the prosecutor of the International Criminal Court requests a person to provide information regarding the conduct of investigations, and the latter makes false statements or conceals what they know "about the facts regarding which he/she is heard." This is punishable by imprisonment for up to 4 years.

The penalty for committing the criminal offence of false testimony is imprisonment from 2 to 6 years. The same punishment is provided by law in cases where the deed is legally classified as an offence of false expertise or false interpretation, in which case the punishment applied will also prohibit the offender from working in a particular profession or occupation, ${ }^{41}$ and holding public office. ${ }^{42}$ When individualizing the punishment, the judge should take into account the seriousness of the resulting crime and evaluate the effects of the punishment. The Italian Criminal Code contains the general criteria for assessing the seriousness of the offence committed, ${ }^{43}$ allowing "the judge shall apply the sentence at his/her own discretion" within the limits set by law. ${ }^{44}$ The conditions for impunity are provided for in cases where the guilty party withdraws the false oath "before the final sentence is pronounced with regard to the motion for judgment." 45

\section{Regulation in the Criminal Code of Greece}

As the other states examined in this paper, the Criminal Code of Greece also provides guidelines for managing instances of false testimony, ${ }^{46}$ relating

\footnotetext{
${ }^{37}$ Art. 372 of the Italian Criminal Code.

${ }^{38}$ Art. 371.

${ }^{39}$ Art. 373 .

${ }^{40}$ Art. 371-bis, with the marginal name "False information provided before the prosecutor or the prosecutor of the international criminal court".

${ }^{41}$ Found in the provisions of Art. 30 of part. III, "On ancillary penalties in particular".

${ }^{42}$ The provisions of Art. 373, Para. 1, in relation to Art. 28 of part. III, "On ancillary penalties in particular."

${ }^{43}$ Art. 133.

${ }^{44}$ Art. 132.

${ }^{45}$ Art. 371, Para. 2.

${ }^{46}$ Section XI, with the marginal name "Offences Relating to the Administration of Justice", Articles 224-234.
} 
explicitly to "False Testimony", 47 "False Testimony Without Oath", 48 "False Testimony Committed by an Expert and an Interpreter", 49 and an article including provisions that concern the application of punishments or special cases of impunity. ${ }^{50}$ The analysis of the abovementioned legal texts shows that the legislator distinguishes between the false statement made under oath, and those that are not. Regarding the active subject, the Greek code is quite specific, and relates to such situations as any person who is a party in civil proceedings, ${ }^{51}$ any person examined as a witness under oath, ${ }^{52}$ and any person who is not under oath and who "testifies falsely or denies or conceals the truth" ${ }^{53}$ The expert or interpreter may be the active subject of the offence, ${ }^{54}$ and if they are, in fact, under oath, they will be prohibited from exercising their profession. ${ }^{55}$

The code also specifies that "oath" refers to either the confirmation by the clergy in religious service or the declaration allowed by law in lieu of the oath in the case of people whose religion does not allow them to take an oath.

According to Greek law, giving false testimony is punishable by imprisonment for a minimum of one year ${ }^{56}$ or a monetary penalty. ${ }^{57}$ If the active subject is the expert or the interpreter, the punishment provided by law is at least 2 years of imprisonment.

The law also provides for a case of special impunity when "by their free will, the responsible person revoked before the same authority the false testimony by making a new one." 58 The court has the option of refraining from applying any punishment, ${ }^{59}$ for specific deeds that are committed "in order to avoid criminal liability, either one's own or that of one of one's relatives." 60

\section{Components of the Investigation of the Criminal Offence as Stipulated in the Romanian Legal Regulations}

Witness. The criminal procedural law stipulates that any person may be heard as a witness in the criminal case "if they are aware of facts or factual circumstances that constitute means of evidence." ${ }^{\prime 1}$ This includes people who are part of the fact-finding bodies. ${ }^{62}$ The exceptions, who may refuse to testify

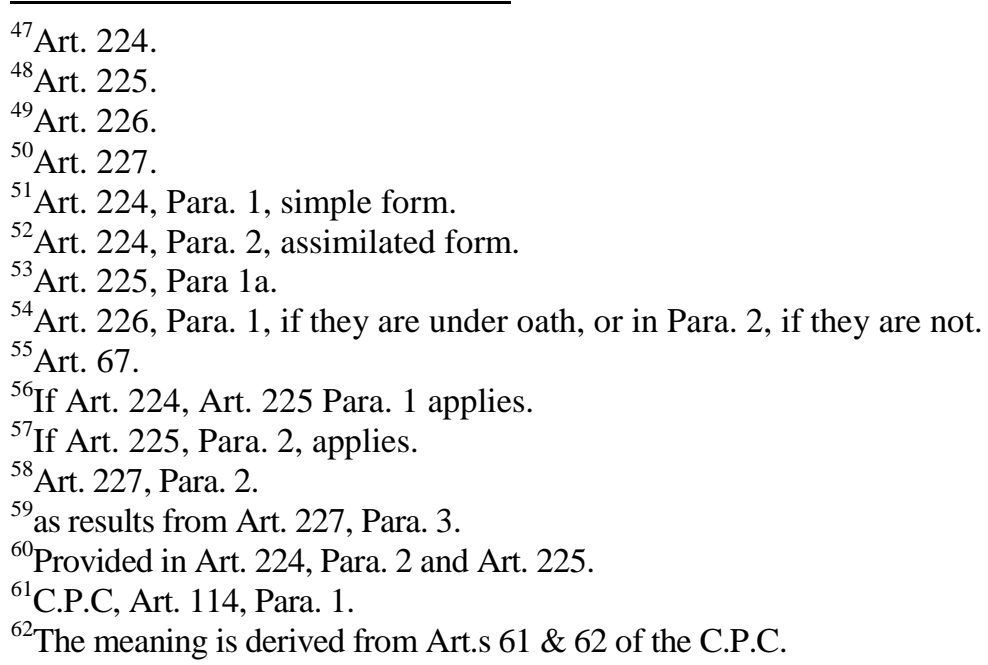


as witnesses, are listed quite clearly in the legal text. ${ }^{63}$ The tactics applicable when hearing a person will be determined by the judicial body, so that it may assess the statements in an objective manner, corroborate the statements and take into account the specific stage of the criminal proceedings.

Witnesses may also be acting of good faith when giving incomplete or inaccurate statements. The process of forming statements is based on the processes of knowing the objective reality, starting from the perceptual process, to the laws of memory preservation and to the way in which things that are known are recounted according to the objective factors and/or concurrent subjective factors that influence this process. The perception process may be influenced both by factors determined by the circumstances of the setting ${ }^{64}$ and the individual's psycho-physiological and personality particularities, including the quality of the sense organs, the individual's personality and education level, age and intelligence, temperament and level of thought process mobility, states of fatigue, affective states, attention and distortion factors (e.g. excessive influence of perceptions from previous experiences). ${ }^{65}$ We must consider the fact that in order to be an active subject of this offence, the following conditions must be present: the witness must intentionally commit the action or omission, not saying everything they know in response to the question, in the specific, solemn context of the trial, in the presence of a number of participants (publicity of the court sessions), after they reacted differently in the criminal prosecution stage, sometimes contrary to everything they are stating at the trial. ${ }^{66}$

Interpreter. According to the Romanian Criminal Procedure Code (henceforth the C.P.C.), hearing testimony mediated by as interpreter takes place when the person being heard "does not understand, does not speak or does not express himself/herself well in Romanian." 67 Thus, a certified interpreter must be appointed. Exceptions are allowed in cases where either an urgent procedural measure is required or interpretation by a certified interpreter cannot be provided. ${ }^{68}$

Expert. After the appointment of the expert, either by the criminal prosecution body or by the court, the expert will be aware of the objective of their expertise, as well as the questions to be answered. According to the regulations ${ }^{69}$ regarding their realm of expertise, the expert has the right to propose modifications or completions to the questions. In addition, the judicial body will indicate to him the purpose of their analysis and the basis upon which the conclusions will be drawn. In cases where the expert is appointed by a "forensic institution, a laboratory of forensic expertise or any specialized institute," an exception will be made regarding the rule of meeting with the judicial body before providing

\footnotetext{
${ }^{63}$ Art. 117 , paragraph 1 of the Criminal Procedure Code: “a) a suspect's or defendant's spouse, ancestors and descendants in direct line, as well as their siblings; b) persons who were a suspect's or defendant's spouse."

${ }^{64}$ Mircea (1999) at 255-256.

${ }^{65}$ Stancu (2008) at 416-418.

${ }^{66}$ Butoi (2012) at 130.

${ }^{67}$ C.P.C. Art. 105, Para. 2.

${ }^{68}$ Iancu, Şinca \& Şinca (2018), 2860-2865.

${ }^{69}$ C.P.C. Art. 177.
} 
expert services. $^{70}$ In order to demonstrate the constitutive elements of the offence of false testimony, taking into account the capacity of the active subject in the process of investigation of the offence, a follow-up plan will be drawn up, beginning with the questions formulated and the answers provided by the expert. This will take place regardless of the manner in which the expert was appointed, the appointment procedure, the type of expertise and its performance.

An expert may also be present during the procedural activities related to the criminal investigation or trial. While being heard by the criminal prosecution body or by the court, the expert might provide untrue answers. If an expert signs the expertise report by themselves, they will be the perpetrator of the offence, and if they sign the report along with other experts, they will be a co-perpetrator. Along with the criminal procedural regulations, ${ }^{71}$ A government ordinance also regulates the forensic expertise activity ${ }^{72}$ and relates to the types of expertise that may be requested during the judicial process and the basic requirements for being appointed an expert allowed to participate in this process.

Protected Witnesses. ${ }^{73}$ The C.P.C. ${ }^{74}$ defines the concept of a threatened witness, ${ }^{75}$ as well as the measures that must be taken during a criminal prosecution $^{76}$ or trial. ${ }^{77}$ Specific regulations are provided for the hearing of a protected witness, a capacity that aggravates the deed in the event that they make false statements. ${ }^{78}$ A relevant status is that of the vulnerable witness. ${ }^{79}$ A protected witness may give their statement without being physically present at the place where the judicial body is located, and the medium on which it was recorded "in the original, sealed with the seal of the prosecutor's office or, as the case may be, of the court before which the statement was made, shall be kept confidential."

Undercover Investigator. The C.P.C ${ }^{80}$ regulates the investigation procedures in which an undercover investigator is used: "the use of a person with an identity other than their real one." event that the purpose is to obtain "data and information regarding the commission of a crime". If, in connection with the activities carried out based on the mandate received, the undercover investigator is subjected to threats, intimidation or other acts of violence, the law states that they may benefit from the same protection

\footnotetext{
${ }^{70}$ C.P.C. Art. 177 in relation to Art. 173, Para. 3.

${ }^{71}$ C.P.C. articles $172-191$.

${ }^{72}$ Government Ordinance no. 75/2000, Regarding the organization of the forensic expertise activity, published in the Official Journal no. 407 of 29 August 2000, with subsequent amendments and additions.

${ }^{73}$ Law no. 682/2002, regarding witness protection, republished in the Official Journal. no. 288 of 18 April 2014.

${ }^{74}$ in Chapter II "Hearing of Persons", Section 5 "Witness Protection".

${ }^{75}$ Art. 125.

${ }^{76}$ Art. 126.

${ }^{77}$ Art. 127

${ }^{78}$ Art. 129.

${ }^{79}$ Art. 130, Para. 1a: "the witness who suffered a trauma as a result of the commission of the offence or as a result of the subsequent behaviour of the suspect or defendant"; Para. 1b: "underage witness".

${ }^{80}$ Art. 148 ("Use of undercover or real-identity investigators and of informants") and Art. 149 ("Measures for the protection of undercover investigators and informants").

${ }^{81}$ Art. 138, Para. 10.
} 
measures as witnesses. The benefit of protection measures may also be arranged to include their family members.

\section{Findings/Results}

Romanian case-law includes cases that necessitated the resolution of a legal issue in the matter or filing an appeal in the interest of the law. Within the context of this paper, regarding a person who makes a false statement, it must be noted that such a witness may be an active subject of the offence of false testimony, ${ }^{82}$ but not an active subject of the offence of aiding and abetting a perpetrator. ${ }^{83}$ There are also cases where a person is heard as a witness, and if, during that procedure they perform the action or inaction as provided for by the legislator in the Criminal Code, ${ }^{84}$ they will be an active subject ${ }^{85}$ of that offence only, and will not be considered to have perpetrated the offence of aiding and abetting a perpetrator. ${ }^{86}$ We would also like to emphasize the importance of expressly addressing the witness with the question referring to the essential requirements related to the objective side, in order to clarify the circumstances or facts that are essential in the investigation or resolution of the case, and as a condition $^{87}$ for achieving the objective side of this offence. This assessment, emphasising the essential nature of the circumstance, relates to "evidentiary efficiency, relevance and conclusiveness", and is relevant "regardless of whether the court that resolved the case removed from the evidence administered the statements given by the witness as insincere". ${ }^{88}$

There are cases in which the fact-finding bodies ${ }^{89}$ conclude fact-finding reports regarding facts that may be legally classified as a crime, and such bodies may be heard in the capacity of witnesses. The act concluded by the fact-finding bodies $^{90}$ is "an act of seizing (notification of) the criminal investigation bodies." 91 The case-law includes situations in which the fact-finding body also carried out a criminal investigation in the same case. In one such case, the judge conducting the preliminary hearing maintained that, based on the report, the criminal investigation

\footnotetext{
${ }^{82}$ In this respect, "Decision no. 1/16 January 2020 regarding the issuance of a preliminary ruling on the resolution of a point of law", High Court of Cassation and Justice, court panel for resolving legal issues in criminal matters, published in the Official Journal no. 173 of 3 March 2020, RO.

${ }^{83}$ Romania Criminal Code, Art. 269.

${ }^{84}$ Art. 273, Para. 1.

${ }^{85}$ In this respect, "Decision no. 1/14 January 2019 on the appeal in the interest of the law declared with regard to the deed of a person heard as a witness...", the High Court of Cassation and Justice, the court panel with jurisdiction to rule on the appeal in the interest of the law, published in the Official Journal no. 187 of 8 March 2019, RO.

${ }^{86}$ Art. 269, Para. 1.

${ }^{87}$ In this respect, "Decision no. 53 of 22 January 2019", published in the Official Journal no. 347 of 6 May 2019, RO.

${ }^{88}$ In this respect, "Decision no. 1319/2016, pronounced by the High Court of Cassation and Justice Criminal Division", published in the Official Journal no. 347 of 6 May 2019, RO

${ }^{89}$ As defined in Art. 61.

${ }^{90}$ In accordance with Art. 61, Para. 1.

${ }^{91}$ Art. 61, Para. 6.
} 
had been carried out by the same fact-finding body that had the capacity of a criminal investigation body, and this led to the annulment of the gathered evidence, by reason of the evidentiary processes ordered. Thus the fact-finding bodies acquire the capacity of a witness, through the provisions of the criminal procedural law. $^{92}$

Possible active subjects must conduct themselves adequately, within the values defended by the legislator through the laws containing criminal provisions. This is reflected in the punishments provided by law in the case of false testimony, the focus of this study: the special minimum prison sentence is six months and the special maximum is five years, and may be substituted by a fine. in any case, the punishment provided by law should be individualized, established and applied by the court, depending on the defendant's situation. It should also have educational values, contributing to the prevention of crime.

The subjective attitude of the perpetrator, as reflected by the actions/ omissions committed intentionally before the judicial bodies, creates distrust around and within the bodies involved in the administration of justice. Punishments that lean towards the special maximum would, most probably, discourage the perpetration of further criminal acts, also conveying the message that the judicial bodies act firmly in their application of the law and ensuring order and safety in the community.

Our analysis of the incriminations of false testimony, provided in the penal codes of the states referred to in this article, has found that:

a) Although the act of perjury is criminalized in all European countries, differences in legal content, as well as various marginal names, make it difficult to compare the relevant legal rules, especially in ambiguous situations such as those involving transitory people, occurrences that take place during judicial proceedings, without taking an oath or in the case of corporate crisis.

b) The use of marginal names translated from other languages or notions specific to criminal law can create confusion, lead to ambiguity between the variants of translated texts, make it difficult to understand the text of the law or create confusion in similar hypotheses, leading to behaviour inconsistent with the criminal law of different states. While the Romanian legislator relates to the legal content of the crime of "False Testimony", 93 there are translations that use the word "Perjury". This ambiguity may also occur regarding the definition of such terms as expert, protected witness, threatened witness and vulnerable witness, for example.

c) Comparing the marginal name "False Testimony", we have found that it is used to denote the same meaning as defined by the legislator in the criminal codes of Romania, Hungary, Italy, Greece. However, the criminal codes in Germany, Greece and Italy also detail similar crimes with different marginal names, differentiated by their components, such as whether the crime of false testimony was committed under oath or without

\footnotetext{
${ }^{92}$ More specifically Art. 114, Para. 4.

${ }^{93}$ Art. 273.
} 
taking an oath. In Italy there is a text of law that explicitly refers to false testimony given under oath, taken as part of the civil process. Only in Germany is there a section entitled "Perjury" which is often used in legal language. ${ }^{94}$

d) in Germany and Greece the legal content differentiates between a false statement made without taking an oath and a false statement made under oath, but at the same time takes into account the active subject, the circumstances or the type of case in which the persons are heard.

\section{Discussion}

Article 273 of the Romanian Criminal Code provides for the legal content of the criminal offence of "False Testimony" (Perjury). In addition, the legislator has provided other relevant special laws, such as laws indicating the legal definition of the concepts of expert, protected witness, threatened witness and vulnerable witness.

Having examined the legal texts of certain European states (Romania, Germany, Hungary, Italy, and Greece) and compared the manner in which they relate to the subject of "false testimony", we have found the following:

1) We find the same marginal name "False Testimony" (or "Perjury") given by the legislator in the criminal (penal) codes of Romania, Hungary, Italy and Greece, though the criminal codes of Germany and Greece refer also to other crimes, with different marginal names, based upon the different components of the case, depending on the situation in which the person makes their untrue statements (under oath or without taking an oath). In Italy there is a legal text that explicitly refers to the false oath made within the context of a civil trial.

2) The legal content of the offences in Germany and Greece differentiates between a false statement made without taking an oath and a false statement made under oath, and the circumstantiation of the active subject;

3) The legal object emerges from the chapter/section in which the legislator included the crime of false testimony, as follows: in Italy and Greece, the protected values are related to the administration of justice, in Romania they are related to the achievement of justice, in Hungary the protected values are related to the judicial system, and in Germany, to the activity of the judicial bodies, implicitly the activity of the courts.

4) The active subject related to the marginal name of "False Testimony" is similar in the legislations of Romania and Hungary, in the sense that they are found in similar capacities (witness, expert, interpreter). By contrast, we note that the Romanian Criminal Code has a different legal classification for a witness (simple form), as opposed to a witness with a protected identity, a witness included in the Witness Protection Program or an undercover investigator (aggravated forms). In the Hungarian Criminal

\footnotetext{
${ }^{94}$ Section 154 of the German Penal Code.
} 
Code, the special adviser and the translator are mentioned among the active subjects. The Italian Criminal Code refers only to the witness as the circumstantiated active subject of the offence. The expert or interpreter are included as possible active subjects under other offences with distinct marginal names, but containing a similar material element.

5) The analysis of the legal texts in the states indicated above shows that the subjective side, i.e. guilt, is in the form of intention. The Hungarian Criminal Code, in addition to intention, contains a specific negligence as a form of guilt ${ }^{95}$ and the German Criminal Code includes a section providing that criminal acts of false oath committed through fault are punishable. ${ }^{96}$

6) Special causes of punishment are emphasised in the codes of Germany and Hungary.

7) Causes of impunity are emphasised in the codes of Romania, Hungary, Italy, and Greece.

8) Causes for nonenforcement of the punishment, left to the discretion of the courts, are emphasised in the codes of Hungary, Germany and Greece.

9) The penalties provided by law are different. In some states, the special minimum punishment is indicated. In Germany, for example, the penalty for mild forms of the crime is imprisonment for at least three months. In Romania, the penalty is imprisonment for no less than six months. We find an unspecified special minimum punishment, but a specified special maximum punishment in Hungarian legislation, e.g. imprisonment for up to one year or imprisonment for up to three years. As for the special maximum punishment, it may be as high as eight years in Hungary, if the false testimony refers to a crime for which the maximum punishment is life imprisonment. The criminal law of Greece provides for a specified minimum punishment, such as imprisonment for at least one year, without specifying a special maximum punishment.

\section{Conclusion}

In the current context, the truthful accounting or offering of true answers is of significant importance, specifically in procedures intended to ensure and maintain public order and safety. In order to identify the best solutions to the problems that occur as a result of certain concrete situations, it is important to be aware of the psychological processes involved in the formation of statements in the conscience of participants in the criminal proceedings or other judicial procedures. Being aware of general elements that are of interest to humankind, especially good Euroregional governance, ensures human safety and contributes to the construction of social capital even when paradigms change. Communication in situations of uncertainty is affected by a number of needs, and therefore one factor influencing the development of our accounts is how safe we feel in our given situation at a specific time.

\footnotetext{
${ }^{95}$ Para. 6 of the Art. refering to the offence.

${ }^{96}$ Section 161.
} 


\section{References}

Butoi. T. (2012). Psihologie judiciară (Forensic Psychology). Bucharest: TREI Publishing House.

Cioclei, V. (2016). Manual de criminologie (Criminology Manual), 6th Ed. Bucharest: C.H. Beck Publishing House.

Duvac, C. (2010). Drept penal. Partea specială (Criminal Law. The Special Part), Vol. I. Bucharest: C.H. Beck Publishing House.

Iancu, (Nechita) E.-A. Şinca, M.-G. \& T. Şinca (2018). "Considerations Regarding the Use of Interpreters and Translators in Technical Surveillance Activities" in Revista Română de Criminalistică (Romanian Journal of Forensic Science), No. 2/2018, Vol. XIX, ISSN 1454-3117.

Lopez, E.M. Y (2009). Manual de psihologie juridică (Manual of Legal Psychology). Bucharest: Oscar Print Publishing House.

Mircea, I. (1999). Criminalistica. Bucharest: Lumina Lex Publishing House.

Stancu, S. (2008). Tratat de criminalistică (Forensic Science Treatise). Bucharest: Universul Juridic.

C.P.C. - Romanian Criminal Procedure Code (Law no. 135/2010 on the Criminal Procedure Code, published in the Official Journal no. 486 of $15^{\text {th }}$ July 2010, Criminal Code published in the Official Journal no. 510 of $24^{\text {th }}$ July 2009).

Criminal Code of Romania - Law no. 286 on the Criminal Code published in the Official Journal no. 510 of $24^{\text {th }}$ July 2009.

Law no. 682/2002 on witness protection, republished in the Official Journal no. 288 of $18^{\text {th }}$ April 2014, as well as in the Criminal Procedure Code, Section 5, with the marginal name "Witness Protection" (Articles 125-130) in Chapter II "Hearing of Persons" contained in Title I, with the marginal name "Evidence, Methods of Proof and Evidentiary Processes".

Romanian Constitution - The Constitution of $31^{\text {st }}$ October 2003, published in the Official Journal, Part I, no. 767 of $31^{\text {st }}$ October 2003, as amended and supplemented by the Law on the revision of the Romanian Constitution no. 429, published in the Official Journal, Part I, no .758 of $29^{\text {th }}$ October 2003. 
